\title{
Correction to: Effects of a resistance training programme in people living with HIV in Zimbabwe
}

\author{
Victor Mbayo ${ }^{1} \cdot$ Takshita Sookan $^{1}$
}

Published online: 17 August 2020

C) Springer-Verlag Italia S.r.l., part of Springer Nature 2020

\section{Correction to: Sport Sciences for Health}

$$
\text { https://doi.org/10.1007/s11332-020-00658-y }
$$

Unfortunately, the first author name was not included in the author group of original publication. The complete correct name is given below.

Victor Mbayo

The original article has been updated.

Publisher's Note Springer Nature remains neutral with regard to jurisdictional claims in published maps and institutional affiliations.

Takshita Sookan

Sookan@ukzn.ac.za

1 Durban, South Africa 